\title{
THE DEIR AL-ZAFARAN AND MARDIN GARSHUNI ARCHIVES
}

\author{
KHALID DINNO
}

UNIVERSITY OF TORONTO

\begin{abstract}
Garshuni was the writing format of choice for the majority of the Syrian Orthodox Communities in the Ottoman Empire, particularly those in Anatolia. Using a Syriac script to express an Arabic text (Arabic Garshuni) served more that one purpose. It exhibited reverence to the very language that was spoken by Jesus and His Disciples, which was a marker of these communities' identity. It also offered a measure of privacy in communication against outside intrusion. With nearly half of the archival material found in Deir al Zafaran and in Mardin being in Garshuni Arabic, these archives offer a unique opportunity to explore the format and use of this mode of writing among these communities. This paper aims to provide a window on the potential for further such studies.
\end{abstract}

\section{INTRODUCTION}

Recent access $^{1}$ to the patriarchal archives of the Syrian Orthodox Church in Deir al-Zaefaran (Dayro d-Kurkmo, Saffron Monas-

1 Permission from His Holiness, the late Zakka I Iwas, of blessed memory, Patriarch of the Syrian Orthodox Church made this access possible. This permission is respectfully and duly acknowledged. 
tery), ${ }^{2}$ and in the Church of the Forty Martyrs in Mardin has yielded an enormous wealth of information. Much of this is contained in the correspondence to and from the patriarchate over a period of time that spans more than one century beginning from the early 1820s.

Being the seat of the Patriarchs of the Syrian Orthodox Church over nearly seven centuries, Deir al-Zaefaran was the major depository of church documents for a long time. However, due to the ravages of time, particularly the repeated Kurdish incursions, this monastery lost most of its library and archive material. ${ }^{3}$

With Arabic Garshuni figuring prominently as the medium of expression in this archival material, this material constitutes an excellent depository of Arabic Garshuni manuscripts. This paper aims to provide a preliminary study of the Arabic Garshuni.

All materials found had been stored without being catalogued. The material in Deir al-Za faran had been stored in random batches, each two to four inches thick, whereas the material in Mardin had been bound in volumes. This was believed to have been done by, or under the directions of, Bishop Youhanna Doulabani (d. 1967).

Most of the imaging (copying) work in Deir al-Za faran and all of that in Mardin was carried out in July 2010 by a team that included George Kiraz and myself. Earlier imaging work of some of the material at Deir al-Za faran had been carried out in 2005 and 2007 by a team that was headed by George Kiraz. The imaging work involved taking nearly 19,000 images.

The majority of this archival material consisted of letters written to the patriarch of the day from a variety of sources from within the church and community, as well as from outside sources. This material also included telegrams, financial accounting data, draft letters, and internal reports and internal correspondence.

2 Deir al-Zaefaran, located approximately eight $\mathrm{kms}$ to the east of Mardin, was the seat of the Syrian Orthodox Patriarchate from the thirteenth century to the early 20 s of the twentieth century.

3 In his book Narrative of a Visit to the Syrian (Jacobite) Church of Mesopotamia (New York: D. Appleton, 1844), p. 225, Horatio Southgate reports that when he wished to visit the monastery's historic library, the bishop who accompanied him apologized for the library's depleted contents, as "the Kurds had used most of the ancient codices as wadding for their guns during their last occupation of the establishment." 
The imaging work naturally involved careful handling of archival material as photographs were taken of the front (recto) and back (verso) of documents. Some of the documents were now mere scraps of the original, having deteriorated as the result of age or poor storage. The number of complete, readable folios, excluding blank versos, or versos with minimal information, that could be formed from the entire collection of images, is naturally considerably smaller than the estimated total. In the absence of appropriate cataloguing, this number may be estimated to be about one half of the total.

A sample of letters is attached (see Figures 1-3). Figure 1 (Image No. K05-0873) is a letter in Syriac addressed to Patriarch Jacob II, sent from Malabar, India. The letter discusses what was for a long time an ongoing issue concerning Athanasius, a pretender to the rank of Mutran in Malabar. Figure 2 (Image No. K05-0046) is a letter in Garshuni from Mutran Alias (Elias) to Patriarch Peter III, dated February 11, 1888. Figure 3 (Image No. K10-B20-0760) is a letter in Garshuni from a number of clergy to Patriarch Peter III dated November 18, 1887, recounting the unsatisfactory conditions within their churches.

\section{ANALYSIS OF THE DEIR AL-ZA ${ }^{e} F A R A N$ AND THE MARDIN COLLECTIONS}

Because of the immense volume and diversity of the archival material, a complete analysis of the collected material could only be conducted by several teams working long-term. A study is currently underway to gain, as much as possible, a perspective of the state of the Syrian Orthodox Church and its community in the nineteenth century. ${ }^{4}$ This perspective includes the state of its dioceses, its ecclesiastic structure, the church's relations with other churches and with the Sublime Porte, the socio-economic condition of its communities, and inter-community relations.

To serve the intended study, a large proportion of the archival material has been reviewed and its contents analyzed. The analysis has been based on the following parameters: period; source

4 See also: Khalid Dinno, "Accessing the Archival Heritage of the Syrian Orthodox Church: Prelimenary Report," Journal of the Canadian Society for Syriac Studies 13 (2013)-pp. 88-97. 
(sender) identity; source geographic provenance; subject matter, or issue; and language of correspondence.

The study of the language employed in this archival material, which is what is of interest here, has been part of this overall study. While focusing more attention on the question of language, this paper will also make brief references to the questions of source identity and geographic provenance of the letters in this corpus.

\section{Period}

The time period utilized in the archival data analysis has not been limited to a specific date but rather defined in terms of the reign of patriarchs. This was done for two reasons. First, the date is often either not stated or not stated clearly, while the name of the patriarch is almost always stated. Second, given the vast number of documents, grouping them into smaller time intervals, such as in terms of years, would in effect involve cataloguing everything, a mammoth task that is outside the scope of this work. The timeframe for the reigns of patriarchs under question is as follows:

1. Elias II (1838-1847)

2. Jacob II (1847-1871)

3. Peter III/IV 5 (1872-1894)

4. Abdul Masih II (1895-1903)

5. Abdullah II (1906-1915)

6. Elias III (1917-1932)

\section{Document Dating}

Two dating systems were in use until 1840: the Gregorian for general internal correspondence and the Hijri for correspondence with government. However, as part of the 1839 Tanzimat reforms, the Ottomans used the Rumi calendar when referring to civic matters. The Rumi calendar, which had a Julian year length, was adopted on

${ }^{5}$ He was conventionally known as Peter III during his lifetime, and this is the way his name appears in the archival material discussed here and on his epitaph. The correction in designation was made in the 1920s upon a historical review of past patriarchs with this name who sat on the seat of Peter the Apostle in Antioch (counted as Peter I). These included Peter II (the Fuller) (470-471) and Peter III of Raqqa (571-591). This last Peter was known as Petra and was, for this reason, not counted. 
March 30, 1840, Julian (corresponding to March 1, 1256 AH). ${ }^{6}$ There was no strict adherence to the Rumi calendar, and the Gregorian continued to be used often along side the Rumi calendar.

\section{Source (Sender) Identity}

Letters to the patriarch of the day came from a variety of sources. These included ecclesiastics: bishops, priests, and monks; church wardens and community dignitaries, ordinary folk: individuals and groups of individuals; other Christians and Christian churches; Muslim neighbors; municipal and regional authorities; foreign diplomatic sources; and last, but by no means least, the Sublime Porte.

\section{Geographic Provenance}

It was difficult to determine the precise geographic source of many of the letters since in many cases the geographic location of the sender was either not clearly stated or not stated at all, presumably on the assumption that the sender was known to the patriarch. In many other cases the senders' locations were minor villages whose names were subsequently erased or changed by the Turkish authorities following World War 1. However, in most cases it was still possible to identify location from content or from recurrence of sender names, particularly in the case of clergy and community dignitaries.

\section{Typical Results: Sender Identity and Geographic Provenance}

Figure 4 provides a summary of the results relating to sender identity and geographic provenance for the letters addressed to Patriarch Peter III. The summary shows that nearly $44 \%$ of the letters came from ordinary people, as individuals or groups. This remarkable accessibility of the patriarch is indicative not only of the close interaction between the patriarch and his people, but also that writing to the patriarch yielded positive outcome. The figure also

6 Thus, the difference of 584 years between the two calendars remains constant. Accordingly, a document dated August 14, 1305 would correspond to August 14, 1889 in Julian calendar and August 26, 1889 according to the Gregorian calendar. The 12-day difference between the Julian and the Gregorian calendars increased to 13 days in 1900. 
shows that the bishoprics in Anatolia likely consumed the lion's share of the patriarch's time.

\section{Language}

The majority of the documents were written either in Ottoman Turkish, Arabic, Syriac, or Garshuni. A few documents, generally those from India or from European countries, were in English, and even fewer still were in Armenian. Generally, correspondence between the patriarch and the bishops and priests were generally in Garshuni, but in some cases in Syriac. Correspondence with the Ottoman authorities was in Ottoman Turkish. The majority of the correspondence from the Syriac Orthodox communities was in Arabic, or Ottoman Turkish, depending on the location of the source. Letters from Syria and Iraq were generally in Arabic, written in Arabic script or in Garshuni. Letters from Anatolia were more varied with respect to language, but generally in Garshuni Arabic. This variation reflects the variety of languages spoken by the Syriac Orthodox communities in that region. Letters from India were generally in Syriac, but a few were in English.

The entire corpus of documents from Deir al-Za faran and the Forty Martyrs Church can be divided with respect to language as follows: 20\% in Arabic, 27\% in Ottoman Turkish, 2-3\% in Syriac and $48-49 \%$ in Garshuni Arabic, and approximately 2\% in English or other languages.

If we briefly consider the languages spoken by the Syriac Orthodox communities in Anatolia during the nineteenth century, we would find that the residents of Mardin, Bnebile, Qaleat Mara, Ma'serti, Qillith, Isfis and Azikh generally spoke Arabic, while those of Diyarbakir and Kharput spoke partly Arabic and/or Turkish and/or Armenian, while those living further to the north spoke mainly Turkish and/or Armenian. The majority of the people of the Tur 'Abdin region, with Midyat as its main city, spoke Turoyo. Towns speaking this dialect, in addition to Midyat, included Hah, Ainward, Kafro, Kfarzi, Anhil, and Mhaiziz. In the eastern part of Tur 'Abdin, such as Karburan, or further to the east of the Tigris, such as in Bisharie, Kurdish was most commonly spoken, often in addition to one of the other languages noted above. Despite the fact that Armenian and Kurdish were spoken in many places, hardly any letters viewed so far have been found written in these languages. 
There was considerable variety in the form of the Arabic language used, whether written in Arabic script or as Garshuni. This ranged from the moderately literal-classical to the educated mundane, to the very colloquial. The more literal, and the educated mundane versions were generally used by clergy, educated individuals, and dignitaries, particularly in letters from Syria and Iraq. However, even in these cases the letters would likely include many semi-colloquial jargons. This reflected the depressed general state of literacy at that time. The highly colloquial form was generally used by ordinary people. This form included an abundance of "loan" words, most commonly from Turkish, but often also from the Neo-Aramaic of Tur 'Abdin, and less often from Armenian or Kurdish. There was some difficulty in reading these documents, particularly those from local communities, because of the use of colloquial terms and phrases, which could only be overcome with the help of some older people from related communities.

\section{LETTERS TO THE PATRIARCH}

\section{Structure of Letters}

As the Garshuni letters are addressed to a Syriac Orthodox patriarch, they have a special structure, which, as expected, may differ slightly depending on the author. In addition to the interesting content, the formulaic expressions found in the introductions and conclusions of the majority of these letters should be of interest in the wider study of Syriac epistlography.

The following are structural sections within the letters: ${ }^{7}$

1. Address: Some letters express this section in Syriac while others use Garshuni Arabic. The Syriac formula is: حمع من:ما منهئه.

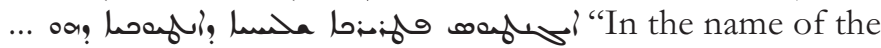
Lord, your Guardian and the Promoter of your patriarchal rank, our venerated father, our lord Mōr Ignatius, Apostolic Patriarch of Antioch..." (K05-0035). The origin of this formula must be found in Syriac letter writing, and

7 Advice from, and review by Amir Harrak are duly acknowledged. Further, the assistance of Fr. Ephrem Adde in deciphering the hand written Syriac script of the Garshuni letters is duly acknowledged. 
one would expect it to start every single letter addressed to the patriarch. This is however not the case, since in other

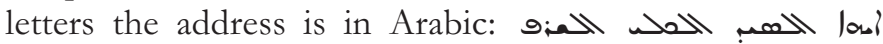

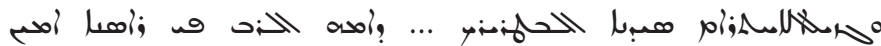
"O lord, most respectable and most honourable, our esteemed lord the Patriarch ... May the Lord keep him as our head, amen" (K05-0046). The variation in the address may reflect the choice of the writers. There are other vocative formulas, similar in wording to the one just given above. Even though the body of the letters is generally in Arabic, the Syriac address gives flavour to communication between the writer and the addressee.

2. Beginning of the Body: The beginning is always deferential, and its wording may vary slightly. Two

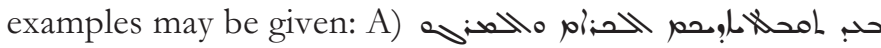
"After kissing your honourable hands and the begging of your good wishes at

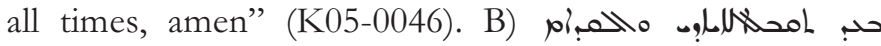
"After kissing the hands and the feet and the begging of wishes and blessing, (in Syriac) Bless my Lord" (K05-0047). These two variations reflect not only Syriac letter writing conventions, but also the choice of Arabic expressions by the writers. In both cases, the senders express their most respect and deference to their religious leaders.

3. Main Body: Right after the deferential beginning, the main subjects of the letters begin in Garshuni. Few Syriacisms are found in the discussion, and the contents are expressed in the colloquial language, which in turn often betrays the background of the writers.

4. Conclusion: The Syriac phrases حمنحم: "Bless my lord and pardon" (K05-0046) almost always end the body of the letters, followed by the dates and signatures. The dates are expressed as in Arabic letter writing: من; "composed on..." (K05-0046). A certain Mr. Barry wrote a letter in 1892 in Garshuni from Diyarbakir addressed to the Patriarch Peter III. He ended his letter with a particular expression which is probably his own: "INiLo wiL "after presenting what (was expressed above) twice and thrice, I beg your good 
wishes" (K05-0087). Bishop Athanasius Shamon's letter of 1882 to the same patriarch ends with a more elaborate formula, given the close relationship between the two

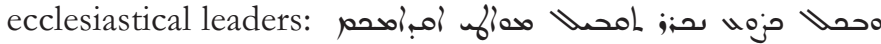

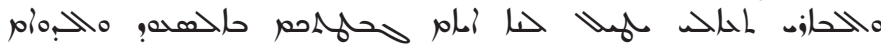
"With entire submission we kiss again your footstep and may the Most High Creator lengthen the days of your Beatitude in success and perpetuity" (K05-0049).

\section{Transliteration Method}

The Arabic Garshuni letters reflect the usual way Arabic phonetic sounds are rendered in Syriac, e.g. jim with a gomal inside which a dot is noted, ghayn with a gomal and a dot below it, etc. Other features that seem to be characteristic of these letters are:

1. Arabic hamza is (a) either avoided; (b) or replaced with $y \vec{a}$; (c) or with $h \bar{a} \dot{a}$; (d) or with simple $\bar{a}$. Examples: (a) (at "wish" (K05-0132, 1.2) for al-du äं; (b) and (K05-0035) for al-khäti ab "the sinful woman;" (c) poai, (K05-0035) for Da $\vec{a} \bar{u}$ " "David;" (d) مامح l (K05-0046 1.3 before the last) for ya'kulhā "he eats it." In some letters the hamza is clearly

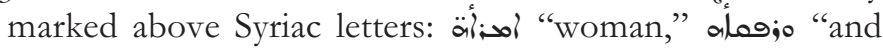
his colleagues" (see for ex. K05-0250).

2. Arabic ghayn rendered with qäf: محما ob05-0046 1.2) "when we saw each other;" this shifting of sounds may reflect a spoken dialect rather than a Garshuni practice. The spelling of the Ottoman currency aid; (K05-0052 1.12) rather than o reflects also a spoken dialect.

3. Short $a$ vowel is sometimes turned into a long $\bar{a}$ : الحسامaمu "the real..." (K05-0172, 1.8) for al-haqiqiyya; هداحه "they did" (K05-0172, 1.10) for fäalü; Lowias "they made us understand" for fahbamūnā.

4. Short $i$ vowel rendered with $y \vec{a}$, e.g. en sit" (K05-0249, 1.20) for colloquial là nijlis (Classical la najlus).

5. Final long $\bar{a}$ sometimes rendered with $h \vec{a}$, e.g. (personal name) Șalībā and asog, for (personal name) Șawmā (K05-0172 1. 12-13). 
6. Final $\bar{a}$ rendered with $y \bar{a}$, e.g. م- م: الحب: "the Virgin Mary" (K05-0172, 1.7) for al- adrä.

7. Final $y \vec{a}$ ' rendered with $h \vec{a}:$ aid الح

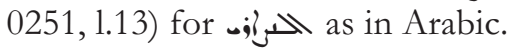

8. The letter $\sin$ is sometimes reduced to zayn: "in the market" for fil-süq (K05-0172 1. 5 from the bottom); this particular word may be colloquial.

9. Doubled letters are sometimes rendered with Arabic shadda, looking like a tilde $(\sim)$, and this is also true for the tanwin, madda, and Arabic vowels. In such letters, the writers intentionally marked the correct pronunciation (see for ex. K05-0393 bottom).

\section{Transliteration of foreign names and words}

The rendering of non-Syriac names and vocabulary depends on the writers of the letters. Some make the effort to transliterate them the way they sound in their original languages. Where this is not the case, the variations in the transliteration are usually also reflected in the bodies of the letters. The following is a sample of unusual renderings of names and words:

\section{Personal Names}

مالمe (K05-0608): Probably the diminutive of Saead, and in this case it should be $\mathrm{Sa}^{\text {ee }}$ òdī rather than $\mathrm{Sa}^{\mathrm{e}} \mathrm{o} d \overline{\mathrm{d}}$.

ماon (K05-0608): Probably the name Jesse and in this case it should be spelled Yassā not Yāsī.

loar (K07-B03-0003 end): The Arabic name ends with short $y \vec{a}$ but here the name is phonetically rendered 'īsā (Koranic name for Jesus).

ir (K07-B03-0003 end): The good Syriac name, lit. "brother," ends with olaph, but the writer wrote it the way it is written in Arabic, with final wäw. Another name ending with long $\bar{o}$ appears with an addional olaph (K05-0052 1. 11): (Bishop) حسبها (of Karbōran). This well-known name among people of Tur "Abdin is the diminutive of Arabic 'Abd-al-'ahad, lit. "Servant of Sunday," that is "Dominic."

(K07-B29-0012 1.4): In Syriac and Arabic the name "Paulus" is written with final semkath/sin, but here the 
letter is emphatic. Sometimes the name is written in Arabic the way it is found in the letter.

(K07-B29-0022, 1.3): This is the diminutive of Jibrāîl "Gabriel" and in Arabic it is written with a final long $\bar{a}$, Jabrā. The shifting of final $\bar{a}$ to $h \vec{a}$ as in this case seems to be a trend in the Garshuni letters (see above).

\section{Geographical Names}

(K07-B03-0016): These two conflicting spellings are found in the same letter. The confusion in the rendering of the name Midyat is understandable since the letter $/ d /$ and $/ t /$ are both dental.

a);ol (K07-B29-0012 1. 3): The name derived from the Syriac Urhoy (Edessa) is often written in Arabic with final long $\bar{a}$, but sometimes with $h \vec{a}$. Whether or not the writer was aware of this variation is not known, but we have seen that this letter shifting often occurs in the letters.

i (K07-B33-0055 bottom): Despite the fact that phonetically it is not easy to pronounce the name "England" as "Inkilterā" in Arabic or spoken Syriac, the writer had no qualms to write it as such! He would have known that, in Arabic, the name is written in print with a $k \bar{a} f$. The name ends with a long $\bar{a}$ in Arabic, but we have seen the shifting of this final $\bar{a}$ to $b \bar{e}$.

مائiحid (K07-B33-0055 bottom): The writer did his best to write Canterbury in Garshuni. The short $\bar{a}$ in the name is lengthened, a feature that we discussed above. It is not known how the final part is vocalized, whether with a long $\bar{a}$ (as in ${ }^{*}$ Cantherburā) or with rbōsōo vowel (as in *Canturbereh).

\section{Vocabulary}

(K05-0035): In the letter the writer complains to his patriarch about the lack of Syriac Orthodox catechism books to teach children religion, a fact which led some to use Catholic and Protestant catechisms. This word (line 3), spelled Kawālkā (?), seems to refer to "Catholics" which should probably be something like Kathālkā. 
ح: K07-0035 1.4): This word probably refers to "Anglicans" in the context of the catechisms, but it is written Brị̀ānā!

fo: lK07-B24P1-0073 1. 11): This term usually and collectively refers to "Protestants," although colloquially it is spelled al-eprot. In this case the author used the voiced labial / $b /$ instead of the voiceless labial / $p /$.

(K07-B24P1-0073 1. 11): Probably a rendering of Syriac "the followers of the Pope, hence Catholics," prefixed with the Arabic article. Here too the voiced labial $/ b /$ is used since Arabic does not have the voiceless labial $/ p /$.

(K07-B29-0022 1. 3 from bottom): The word "polis" with the prefixed article. The voiced labial $/ b /$ replaced the voiceless / $/$ /, and the voiceless, alveolar fricative /s/ was replaced by its emphatic counterpart $/ s$. We have seen the same practice in the name "Paulus" (see above).

pow of (K07-B29-0022 last line): "Your Beatitude," a Syriacism, , (2) of, in Garshuni.

من (K07-B29-0022, 1. 11 and last line): English word "Consul" with the prefixed article and the shifting of the voiced, dental, lateral non-fricative / $/ /$ to the voiced alveolar single flap / r/ (K07-B33-0055, 1.4 before the last). This shifting occurs in colloquial and thus the form found in the letter does not necessarily reflect the writer's personal choice.

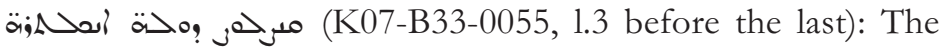
first word is puzzling; is it a literal rendering of English "councils," with the shifting of the sin to emphatic säd? If this were the case, then the Garshuni phrase would mean "the councils of the state of England."

i (K07-B33-0055 bottom): The word means "the English (or) English" and in it the letter $/ g$ / was rendered with a kajf as we saw with the word ägNi (see above). In another letter written by a bishop (K05-0249), the same ethnonym is spelled with final sin, which is phonetically not acceptable: لإبحخم "for the English." 


\section{SAMPLE TRANSLATION}

The letter to Patriarch Peter III appearing in K05-0035 has been selected, as this letter demonstrates a number of features that are common to a large number of letters. The letter is from a schoolteacher in Jazerieh, a region in south-eastern Anatolia that borders north-western Syria. Below is a translation of the address, the first three lines, the last seven lines, and the end. While aiming to convey the contents of the letter correctly, I have attempted to maintain as literal a translation as possible, in order to covey some of the characteristics of expression the author used:

In the name of the Lord, your Guardian and the Promoter of your patriarchal rank, our venerated father, our lord Mōr Ignatius, Apostolic Patriarch of Antioch, who is Peter III, may his prayers be with us.

To you, lord of total honor and immense respect and beatitude, etc (sic). It does not escape your fatherhood that the town of Jazerieh had been abducted by the intruders and continues to weaken from time to time from lack of education, while its children became owned (sic) by the outsiders, the Kawalka (Catholic) millab ${ }^{8}$ and the British 9 millah.

All the children have progressed in the Kawalka (Catholic) Christian education. A single prayer book (we have). We kiss your hands and feet that our request does not return with disappointment, begging, just as the sinned woman begged Christ as she said to Him: "do not let me leave without your blessing, when Satan would then pour scorn on me". ${ }^{10} \mathrm{I}$, too, request your Holiness that I may not return empty-handed and the heretics would then scorn me. In so much as that without what is needed, teaching would not be possible, and this is a sin. Without anyone's permission,

8 The term millah can denote a denomination, people or nation, and may apply to Mualims as well as Christians. However, the Ottoman term millet refers to non-Muslims.

${ }^{9}$ This is a reference to Protestants in this instance.

10 This dialogue does not appear in the New Testament. It is found in the Syriac tradition as an elaboration of the encounter between Jesus and the sinful woman in Mathew 26:6-13, Mark 14:3-9 and Luke 7:37-50. 
and by the safety of my head and my father's head, ${ }^{11}$ and with the hope that our request would not be returned unfulfilled, all according to the will of God. Bless, my Lord, and pardon.

The children of the school kiss your hands and feet.

Dated April 11, 93.

Signed

A worm of the Earth

Yusuf, teacher of the school

The letter provides information about several features: the accessibility of the patriarch to ordinary people, the immense respect with which the patriarch is regarded, and the openness with which matters are stated. The writing style is quite simplistic in term of choice of words, and it is rather disjointed and awkward with regard to sentence construction. This is the case despite the fact that the author is school-teacher. Letters from the less educated or from the uneducated can be more challenging, particularly when colloquial expressions and loan words are extensively used.

\section{CONCLUDING REMARKS}

With nearly $50 \%$ of all correspondence being in Arabic Garshuni, it is reasonable to inquire why this is so; that is, why in Arabic and why in a Syriac script? Is it to do with the addressee or the addresser? The addressee, any of the patriarchs in that period, would have been knowledgeable not only in Syriac and Arabic, but very likely in Turkish as well. On the other hand a very large proportion of these Garshuni letters came from Tur 'Abdin, where Turoyo, was spoken. It would appear that the choice of Arabic was perhaps linked to the elevated position that Arabic held as a language of culture and jurisprudence within the Ottoman Empire, as well as throughout the Asiatic regions of the empire, where Muslims were the majority. It also appears, from interviews with older people with impressions based on oral transmission, that even in Tur 'Abdin, despite its strong Aramaic roots, the ability to communicate in Arabic was considered to be an elitist attribute.

11 This is a form of oath swear, which is characteristic of Middle Eastern cultures. 
The use of Syriac script is somewhat easier to explain: Syriac was considered a holy language in addition to being a marker of the collective identity of the Syriac Churches. Thus the Syriac script carried within it an aura of these attributes. One more factor may be cited: namely, that writing in Syriac provided a degree of privacy from unwanted intrusions and surveillance. This point was demonstrated in some of the letters from the clergy, where the writer suddenly switches from Garshuni to Syriac, when discussing a rather sensitive matter, then back to Garshuni.

Often Ottoman period documents that have been preserved in monastery archives bear a special interest not only for the history of that monastery and the church with which they are affiliated, but also for Ottoman history, whether local or general. The Deir alZaefaran and the Mardin collections are examples of this. The accounts found in the archives describe relations with neighboring Muslim communities, with other Christians, and with the Porte, thus providing valuable insight into contemporary social and political conditions. These accounts, not intended by their authors to be part of a written history, are characteristically free from intended bias, and, because of their large number, should provide particularly valuable testimony on the state of affairs they describe.

As one might expect, the letters dealt with a variety of topics. Many of them from local bishops, heads of monasteries, priests, monks, and wardens responsible for collecting fifes and patriarchal dues, are therefore of an administrative nature. However, what is remarkable to note from these results is the large percentage of letters that were addressed to the patriarch from individuals and groups of individuals on all manner of topics: social, financial, church administration and others. This demonstrates that the patriarchate was readily accessible to ordinary individuals. Yet at the same time, the reverential manner in which the letters were written reflects the esteem with which the patriarch was held by of his people, not only as their highest ecclesiastical leader, but also as their protector and father. This position of the patriarch had been historically promoted in part as a result the social system in the Ottoman Empire in which non-Muslims were organized as semiautonomous millets.

Finally, as the archives contain so much material from ordinary people, particularly from Anatolia, this material can be considered to represent the state of society as viewed from below, a subaltern 
view, as opposed to the elitist view which conventional social history often embodies. This in itself offers a much desired departure from the conventional way of viewing history.

\section{SOURCES}

Dinno, Khalid. "Accessing the Archival Heritage of the Syrian Orthodox Church: Preliminary Report." Journal of the Canadian Society for Syriac Studies 13 (2013): 88-97.

\section{Referenced Archival Documents: ${ }^{12}$}

1. K05-0035

2. K05-0046

3. $\mathrm{K} 05-0047$

4. K05-0049

5. K05-0052

6. K05-0087

7. K05-0132

8. K05-0172

9. K05-0249

10. K05-0250

11. K05-0251

12. $\mathrm{K} 05-0393$

13. K05-0608

14. K05-0873

15. K07-B03-0003

16. K07-B03-0016

17. K07-B24P1-0073

18. K07-B29-0012

19. K07-B29-0022

20. K07-B33-0055

21. K10-B20-0760

${ }^{12} \mathrm{~K}$ stands for archives at Dayro d-Kurkmo (Deir al-Za ${ }^{e}$ faran). 


\section{IMAGES}

Figure 1: K05-0873

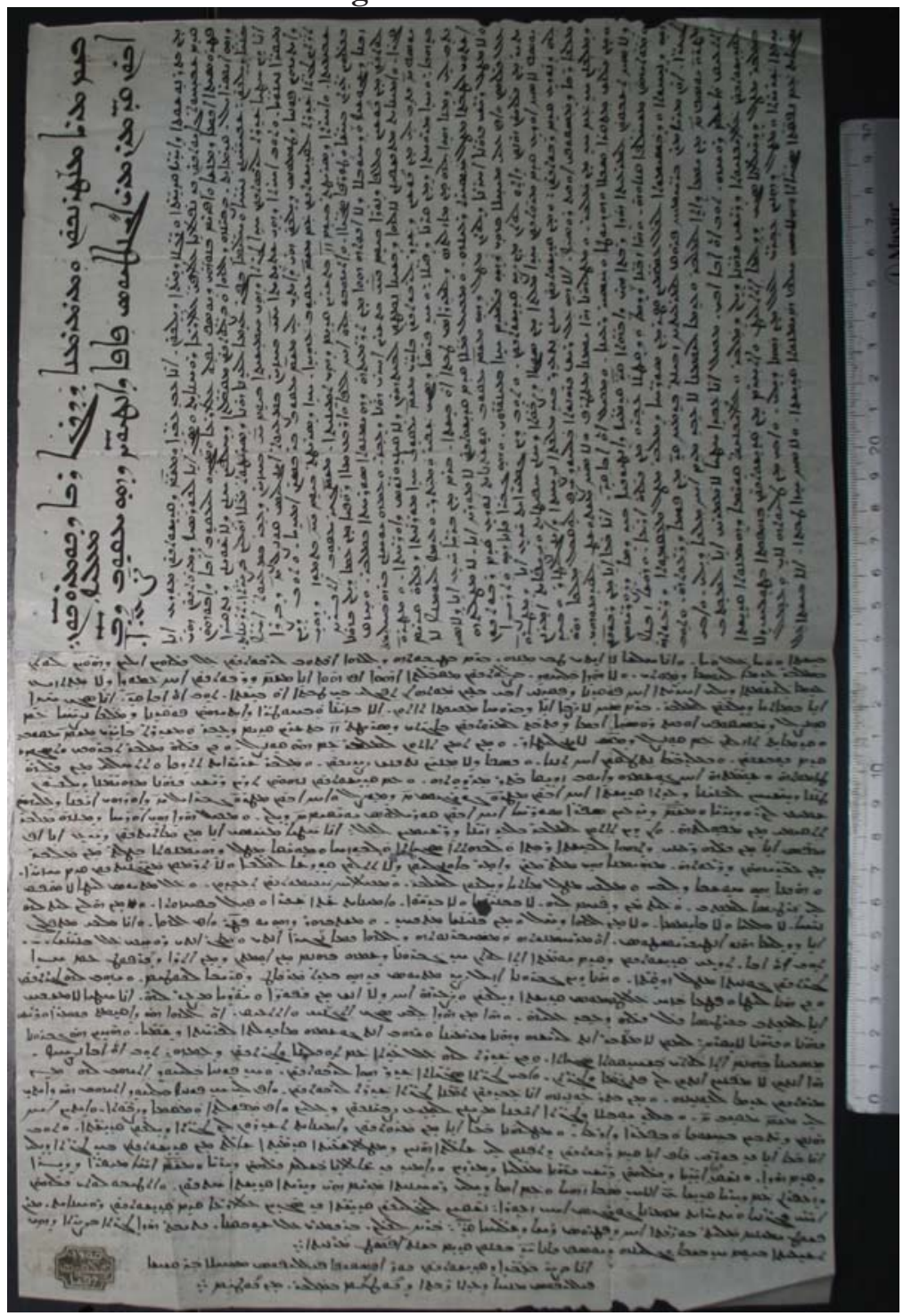


Figure 2: K05-0046

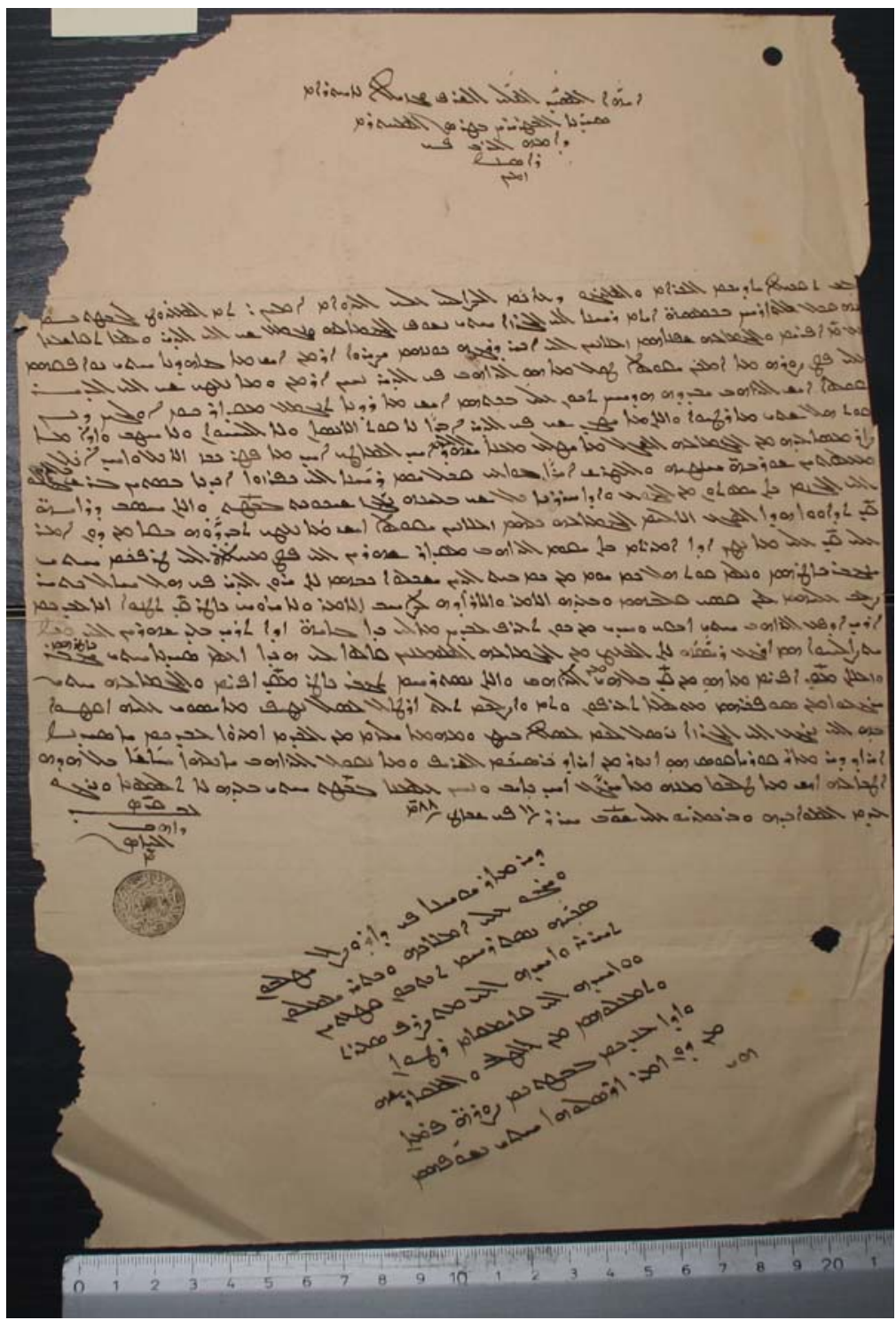


Figure 3: K10-B20-0760

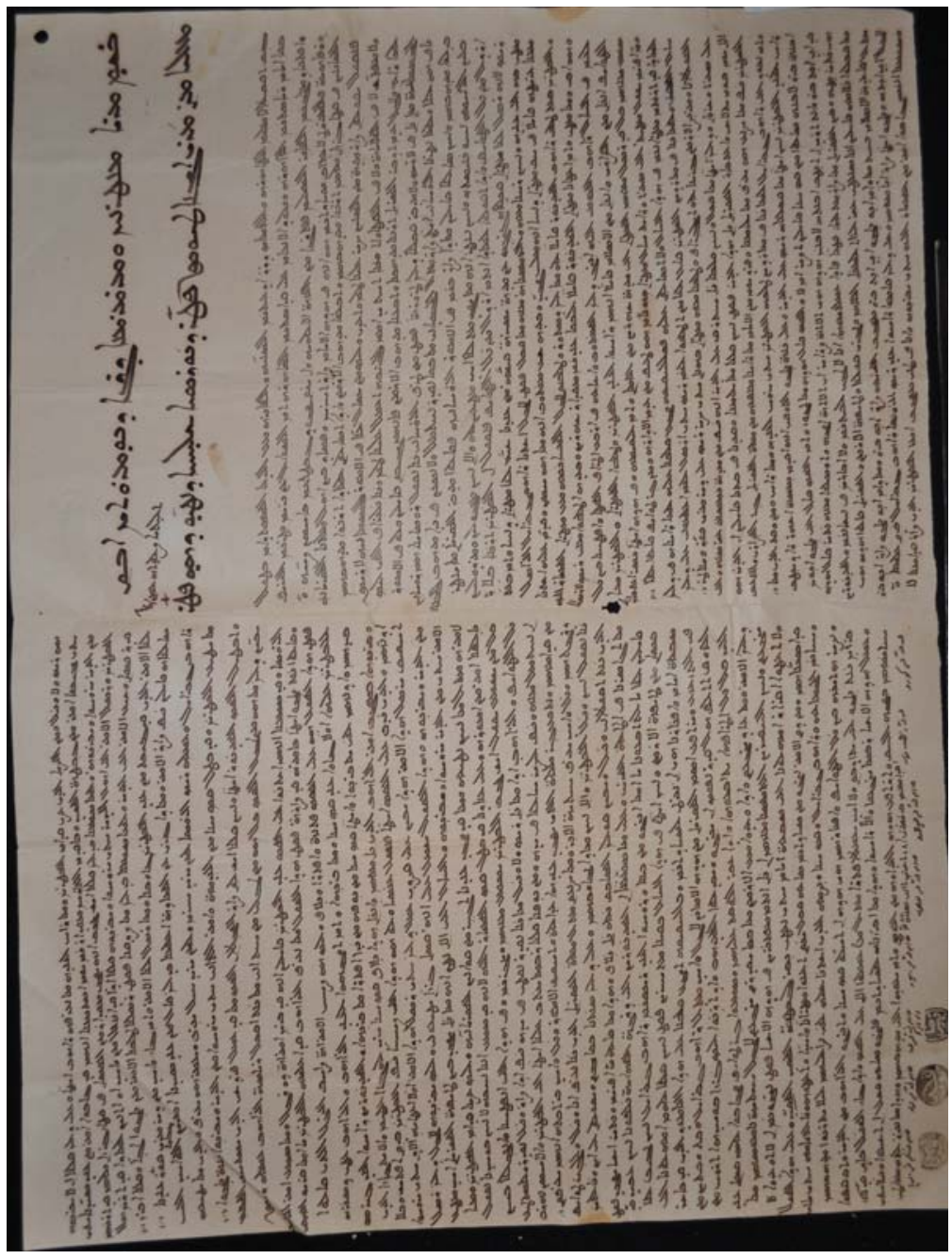


